\title{
The Effect of Diaphragmatic Breathing versus Pursed-Lips Breathing on Pulmonary Functions among Patients with Chronic Obstructive Pulmonary
}

\author{
Disease
}

Eshrak Salama Hashem Mohamed, Demonstrator

Medical Surgical Nursing, Faculty of Nursing, Alexandria University

Laila Mohamed Abdou, Professor

Medical Surgical Nursing, Faculty of Nursing, Alexandria University

Aida Elsayed El-Gamil, Assistant Professor

Medical Surgical Nursing, Faculty of Nursing, Alexandria University

Ahmed Youssef Shaaban, Assistant Professor

Chest Diseases Department, Faculty of Medicine, Alexandria University

\begin{abstract}
Pulmonary rehabilitation plays a key role in the management of chronic obstructive pulmonary disease COPD. It offers supervised exercise and education for those with breathing problems. The nurse plays a key role in identifying potential candidates for pulmonary rehabilitation, and in facilitating and reinforcing the material learned in rehabilitation program. Objectives: 1-Assess the effect of diaphragmatic breathing on pulmonary functions of COPD patients. 2-Assess the effect of pursed-lips breathing on pulmonary functions of COPD patients. 3-Compare between the effect of diaphragmatic breathing and pursed-lips breathing on pulmonary functions of COPD patients. Setting: The study was carried out at Inpatient Medical Chest Disease Unit at Alexandria Main University Hospital. Subjects: a convenient sample of 60 adult patients of both sexes diagnosed with chronic obstructive pulmonary disease, free from co-morbid diseases that affect the result. The sample was divided randomly into two equal groups, 30 patients each. Group (I) received diaphragmatic breathing training, Group (II) received pursed-lips breathing. Tools: Two tools were used in this study. Tool I an interview questionnaire to illicit socio-demographic data, tool II the Chronic Obstructive Pulmonary Disease patient pulmonary functions tests assessment tool. Validity and reliability of the tool were estimated. Results: The study findings revealed that pulmonary function parameters showed only significant changes in tidal volume and expiratory reserve volume after exercise training in both groups. There were significant differences in PaO2, PCO2, SPO2 results among both studied subjects. Conclusion: Diaphragmatic breathing and Pursed lips breathing have almost equal effect on improving pulmonary functions of COPD patients. Recommendation: Patient education regarding pulmonary rehabilitation should be part of the in-service nursing health education programs.
\end{abstract}

Keywords: Chronic Obstructive Pulmonary Disease, Pulmonary rehabilitation, Diaphragmatic and pursed-lips breathing, Pulmonary function parameters. 


\section{Introduction}

Chronic obstructive pulmonary disease (COPD) is a disease state characterized by airflow limitation that is not fully reversible. The airflow limitation is usually both progressive and associated with an abnormal inflammatory response of the lungs to noxious particles or gases. COPD may include diseases that cause airflow obstruction e.g., emphysema, chronic bronchitis or any combination of these disorders ${ }^{(1,2)}$.

The previous definition of COPD has emphasized the terms emphysema and chronic bronchitis. Emphysema refers to abnormal enlargement of the distal air spaces and destruction of the lung distal to the terminal bronchiole. The damage is not uniform, it may affect only the central portion of the pulmonary lobules (centrilobular emphysema) or it may result in destruction of most of the structures within a terminal unit, including the alveolar ducts and alveoli (panlobular emphysema) (figure.1). Chronic bronchitis has been defined as the presence of chronic productive cough for three months during each of two successive years in patients in whom other causes of chronic cough have been excluded ${ }^{(3-5)}$.

COPD is a growing cause of morbidity and mortality worldwide, according to the World Health Organization (WHO), 80 million people worldwide have moderate-to-severe COPD. In 2005, three million deaths due to the disease were reported, and the WHO predicts that, by the year 2030, COPD will become the third leading cause of death ${ }^{(6,7)}$. Alexandria Main University Hospital, statistical reports showed that, 1645 patients were admitted to the Medical Chest Disease Department throughout the year of 2010, and COPD patients represented about one fifth of total admission rate (293 male and 72

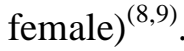

Cigarette smoke has several direct effects on the respiratory tract, its irritating effects can cause hyperplasia of the cells including goblet cells which subsequently results in increased production of mucus and hyperplasia which reduces airway diameter and increases the difficulty in cleaning secretions. Smoking reduces the ciliary activity and may cause actual loss of ciliated cells. It also produces abnormal dilation of the distal air spaces with destruction of alveolar wall after a short time of smoking and changes in small airway function can develop ${ }^{(10,11)}$.

It is believed that many genetic factors increase or decrease a person's risk of developing COPD. The genetic risk factor that is best documented is a rare hereditary deficiency of alpha-1 antitrypsin, which is a significant cause of emphysema in nonsmokers and influences susceptibility to disease in smokers ${ }^{(12)}$.

In the past, most studies showed that COPD prevalence and mortality were greater among men than women. Studies from developed countries show that the prevalence of the disease is now almost equal in men and women ${ }^{(13)}$. COPD is rarely found below the age of 40 , as lung functions deteriorates with age therefore, ageing may increase the susceptibility for the development of COPD and its exacerbations $^{(14)}$.

A history of severe respiratory infection has been associated with reduced lung function and increased respiratory symptoms in adulthood. Also, lung growth which may be related to processes occurring during gestation, birth, and exposures during childhood, reduced maximal attained lung function (as measured by spirometer) may identify individuals who are at increased risk for the development of $\mathrm{COPD}^{(15)}$. The inflammation in the respiratory tract of patients with COPD appears to be an amplification of the normal inflammatory response of the respiratory tract to chronic irritants such as cigarette smoke $^{(14)}$. 
Airway obstruction occurs as a result of the inflammation and narrowing (airway remodeling) and inflammatory exudates in the small airways. Other factors contributing to airflow obstruction include loss of the lung elastic recoil (due to destruction of alveolar walls) and destruction of alveolar support (from alveolar attachments).The airway obstruction progressively traps the air during expiration, resulting in hyperinflation .Hyperinflation reduces the inspiratory capacity and therefore the functional residual capacity during exercise. These features result in breathlessness and limited exercise capacity typical of COPD. Also the stagnant air in the alveoli cannot supply adequate oxygen to the capillaries; this creates a fertile field for bacteria to grow $^{(16)}$.

On the other hand, the trapped air affects the diaphragm, which is the main muscle of respiration as it produces reduction in diaphragm mobility, in which the diaphragm becomes in a lower position than normally expected during expiration and becomes flattened. The flattened diaphragm cannot produce force as effectively as the normal individual, and this may contribute to an increased work of breathing and recruitment of accessory respiratory muscles. Decreased FEV1 primarily results from inflammation and narrowing of peripheral airways, while decreased gas transfer arises from the parenchymal destruction of emphysema ${ }^{(17)}$.

Gas exchange abnormalities result in hypoxemia and hypercapnia; also mild to moderate pulmonary hypertension may develop late in the course of COPD and is due to hypoxic vasoconstriction of small pulmonary arteries, Progressive pulmonary hypertension may lead to right ventricular hypertrophy and eventually to right-side cardiac failure (Cor pulmonale) ${ }^{(18,19)}$.

Although spirometry does not fully capture the impact of COPD on a patient's health, it remains the gold standard for diagnosing the disease and monitoring its progression. Spirometry is the best standardized, most reproducible, and most objective available measurement of airflow limitation $^{(20,21)}$. Lung function measurement by Spirometry; is a simple test to measure the amount of air a person can breathe out, and the amount of time taken to do, so this test can detect very small changes in lung function before the patient can appreciate it. The machine measures the airflow that passes through the inhalation port attached to the machine, the inhalation device is usually a disposable cardboard tube or a reusable tube that can be sterilized after use. The most common parameters measured in spirometry are Vital capacity (VC), Forced vital capacity (FVC), Forced expiratory volume (FEV) at timed intervals of $0.5,1.0$ (FEV1), and Maximal voluntary ventilation $(\mathrm{MVV})\left(\right.$ Figure.1 A,B) ${ }^{(22)}$.

Spirometry measurements are evaluated by comparison of the results with appropriate reference values based on patient's age, height, sex, and race.
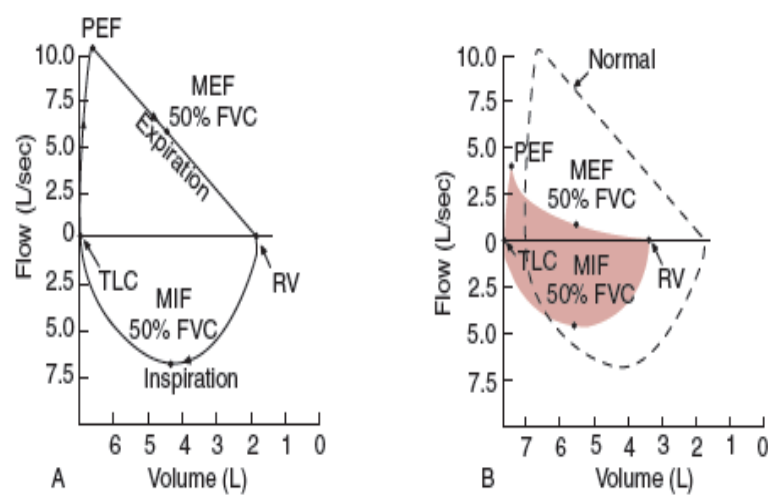

Fig. 1: A) Normal flow volume loop. B) Flow volume loop of obstructive diseases $^{(23)}$.

Spirometry is essential for the diagnosis and provides a useful description of the severity of pathological changes in COPD. It is often repeated after giving the patient a bronchodilator, such as an inhaled beta-agonist. If the FEV1 (forced expiratory volume after 1 second) improves more than 
$12 \%$, the obstruction may be reversible or partially reversible (Table .1).

Table (1): Spirometric Classification of COPD $^{(24)}$.

\begin{tabular}{|c|c|}
\hline \multicolumn{2}{|c|}{$\begin{array}{c}\text { Spirometric Classification of COPD } \\
\text { Severity Based on Post-Bronchodilator } \\
\text { FEV1 }\end{array}$} \\
\hline $\begin{array}{l}\text { Stage I: } \\
\text { Mild }\end{array}$ & FEV1/FVC $<0.70$ \\
\hline & FEV $1 \geq 80 \%$ predicted \\
\hline \multirow[t]{2}{*}{$\begin{array}{l}\text { Stage } \\
\text { Moderate }\end{array}$} & FEV1/FVC $<0.70$ \\
\hline & $\begin{array}{l}50 \% \leq \mathrm{FEV} 1<80 \% \\
\text { predicted }\end{array}$ \\
\hline Stage III: Severe & $\begin{array}{l}\text { FEV } 1 / \mathrm{FVC}<0.70 \\
30 \% \leq \mathrm{FEV} 1<50 \% \\
\text { predicted }\end{array}$ \\
\hline \multirow{2}{*}{$\begin{array}{l}\text { Stage IV: } \\
\text { Very Severe }\end{array}$} & FEV1/FVC $<0.70$ \\
\hline & $\begin{array}{l}\text { FEV1 } 1<30 \% \text { predicted } \\
\text { or FEV } 1<50 \% \\
\text { predicted plus chronic } \\
\text { respiratory failure }\end{array}$ \\
\hline
\end{tabular}

Laboratory studies include arterial blood gas measurement (ABGs) which are usually assessed in the severe stages and monitored in patients hospitalized with acute exacerbation. In the early stages there may be a normal or only slight decreased $\mathrm{paO}_{2}$ and a normal $\mathrm{paCO}_{2}$. In the later stages of COPD, typical findings are low $\mathrm{paO}_{2}$, elevated $\mathrm{paCo}_{2}$, decreased or low- normal $\mathrm{PH}$, and increased bicarbonate $\left(\mathrm{HCO}_{3}\right)$ levels ${ }^{(25)}$.

Pulmonary rehabilitation (PR) plays a key role in the management of chronic obstructive pulmonary disease. It has been defined as "an evidence-based, multidisciplinary, and comprehensive interventions for patients with chronic respiratory diseases who are symptomatic and often have decreased daily life activities. The primary goal of PR is to provide enough patient information, reduce symptoms, decrease disability, restore the patient to the highest possible level of independent function, and improve the overall quality of life (QOL) for patients with chronic respiratory disease. PR includes patient education, therapeutic components, evaluation of nutrition, and psychological support ${ }^{(26,27)}$. Patient education includes respiratory anatomy and physiology as well as simplified explanations of the disease process and therapy The therapeutic components consist of exercise, ventilatory therapy, and ventilatory muscle training. Exercise training including diaphragmatic and pursed lips breathing forms the cornerstone of successful pulmonary rehabilitation. COPD patients are routinely instructed on breathing technique called pursed lips breathing (PLB), in order to improve breathing efficiency and decrease dyspnea during activities, improve physical function and quality of life ${ }^{(28)}$.

The second technique of effective breathing is diaphragmatic or abdominal breathing (DB). In COPD trapped air in the damaged air sacs often causes the lungs to over expand, this prevents the diaphragm which is the most efficient breathing muscle from moving as much, so, COPD patients no longer use this important breathing muscle effectively. Therefore, diaphragmatic exercise is designed to help these patients utilize this muscle in the act of breathing; improve breathing pattern and ventilatory efficiency without causing dyspnea $^{(26)}$.

Adherence to therapeutic interventions including exercise programs is a crucial health behavior in the management of chronic respiratory disease. The nurse should instruct the patient to perform pursed-lips breathing when he/she is relaxed and not in respiratory distress, in pain, or distracted. Also instructs him/her to breathe slowly and rhythmically in relaxed manner and to exhale slowly to empty the lungs. Oxygen supplementation during exercise training has been shown to improve exercise capacity in those patients with COPD, who were not hypoxemic during exercise. Through nurse - patient cooperation, the patients can learn how to cope and improve 
their breathing, fitness, and prevent worsening of the disease. The nurse in pulmonary rehabilitation should provide the patients with the needed instruction about breathing strategies and bronchial hygiene techniques on individualized base, transfer the educational training and exercise adherence to the home setting, and enhance patient's self-management as it improves health status and lowers health service use in many chronic diseases ${ }^{(29)}$. Therefore, the nurses should advice and support patients and their families, educate and encourage them to manage their disease proactively $^{(30,31)}$.

The purpose of this study was to evaluate the effectiveness of breathing retraining of COPD patients (Diaphragmatic and pursed lips breathing) as a coping strategy that can help them improve their breathing pattern.

\section{Aims of the Study}

\section{This study aims to:}

1. Assess the effect of diaphragmatic breathing on pulmonary functions of COPD patients.

2. Assess the effect of pursed-lips breathing on pulmonary functions of COPD patients.

3. Compare between the effect of diaphragmatic breathing and pursed-lips breathing on pulmonary functions of COPD patients.

\section{Operational definition of pulmonary function:}

In the present study pulmonary functions are restricted to the dynamic flow rates of gases through the airways, lung volumes and capacities and the ability of the lungs to diffuse gases.

\section{Research Hypotheses:}

1. COPD patients who practice DB will show improvement in pulmonary functions.

2. COPD patients who practice PLB will show improvement in pulmonary functions.

\section{Materials and Method}

\section{Materials}

Design: A quasi experimental research design was used in this study.

Setting: This study was carried out at the inpatient Medical Chest Diseases Department, Alexandria Main University Hospital.

Subjects: The subjects of this study included a convenient sample of 80 adult patients of both sex diagnosed as having (COPD), who were divided equally into two groups, 40 patients in each group. The number of patients who completed the education intervention was 60 patients, the other 20were dropped from the study due to mortality, tiredness and other unknown reasons.

Group (I) received diaphragmatic breathing training (DBT). Group (II) received pursed-lips breathing training (PLB). Inclusion criteria: Age, ranging from 21 to 60 years, willing to participate in the study, free from any other respiratory disorders such as Tuberculosis, free from any associated co-morbid diseases that affect blood gases results as diabetes mellitus, renal disease and congestive heart failure, and not participate in any respiratory exercise-training program throughout the last 6 months. The required sample size was estimated by using the EPinfo program with the following parameters:

Confidence coefficient $=95 \%$, Power $=80 \%$, Ratio $=1: 1$, Percent $=$ success $50 \%$

The result is $\mathrm{N}=26$ among each of the 2 groups as the minimum. The researcher 
added twenty four to each group in case of withdrawal from the study or dropping out.

\section{Tools:}

\section{Tool I: An Interview Questionnaire}

It was developed by the researcher to illicit the following data: Sociodemographic data as age, sex, occupation, residence, level of education, diagnosis, medications used, smoking habits In addition to the vital signs assessment sheet, (temperature, pulse, respiration, and blood pressure).

Tool II: The Chronic Obstructive Pulmonary Disease Patient Assessment

This tool was developed by the researcher after an extensive review of related literature and applied by a trained technician. It is composed of three parts: pulmonary function test parameters, arterial blood gases analysis, and oxygen saturation measurements.

Part One: Pulmonary function tests (PFTs): This part was used to evaluate the obstructive ventilatory defect through the following parameters: ${ }^{(32)}$

- Vital Capacity (VC), Expiratory Reserve Volume (ERV), Forced Vital Capacity (FVC).

- Forced Expiratory Volume in $1 \mathrm{sec}$ $\left(\mathrm{FEV}_{1}\right) \mathrm{m}, \quad \mathrm{FEV} 1 / \mathrm{FVC}$ ratio (FEV1\%), Peak Expiratory Flow(PEF), Maximum Voluntary Ventilation( MVV) and, Tidal Volume $\left(\mathrm{V}_{\mathrm{T}}\right)^{(32)}$.

Part two: Arterial blood gases analysis: This part was used to assess the ability of the lungs to provide adequate oxygen and remove carbon dioxide through the following: ${ }^{(33)}$ Blood $\mathrm{PH}(\mathrm{N}: 7.35$ to 7.45$)$, arterial oxygen tension $\left(\mathrm{PaO}_{2}\right)(\mathrm{N}: 80$ to 100 $\mathrm{mm} \mathrm{Hg}$ ), arterial carbon dioxide tension $\left(\mathrm{PaCO}_{2}\right)(\mathrm{N}: 35$ to $45 \mathrm{~mm} \mathrm{Hg})$. And, arterial bicarbonate tension $\left(\mathrm{HCO}_{3}\right)$. $(\mathrm{N}: 22$ to 26 $\mathrm{mEq} /$ liter) ${ }^{(33)}$.
Part three: Oxygen Saturation $\left(\mathrm{SpO}_{2}\right)$ : Oxygen saturation of the hemoglobin was measured by noninvasive pulse oximetry. $\mathrm{SpO}_{2}$ (not a substitute for measurement of arterial partial pressure of oxygen) $\left(\mathrm{PaO}_{2}\right)$ (N: 97\%to 99\%) $)^{(34)}$.

\section{Method}

- Written approval: Before conducting the study, an official letter from the Faculty of Nursing was submitted to the general director of the Main University Hospital, and the head of the Chest Department. Permission to carry out the study was obtained from the director of the chosen setting after explanation of the purpose of the study.

- Validity and Reliability: The study tools were developed by the researcher after reviewing the related literature. The content of the constructed tools were revised by a jury of 7 experts in the field of medical surgical nursing, Faculty of Nursing, Alexandria University, to test the content validity, completeness, and clarity of items.

- Pilot study: Before starting the data collection, a pilot study was applied on ten patients to test the clarity and applicability of the tool, time needed to conduct the interview and the intervention, and necessary modifications were introduced.

- Procedure: The study was conducted throughout a period of 9 months (from August 2011 to April 2012). It comprised three phases:

- Phase I (pre-exercise phase): Patients who fulfilled the inclusion criteria were selected and allocated either in group I (DB) or group II. (PLB) Patients were asked to fill the interview questionnaire themselves or with the help of the researcher. The patient's age, sex, height and 
weight were recorded for calculation of reference values.

Scheduled appointments were given to them to conduct the lab investigations and pulmonary function tests that were carried out by the technician at the pulmonary function test lab, Chest Disease Unit at the Main University Hospital. Patients were asked to be relaxed as possible before and during the test and follow instruction during procedure.

- Nose was pinched off as the patient breathes through a mouthpiece attached to the spirometry.

- For Vital capacity (VC): The patient was instructed to breathe in and out normally to attain full expiration. For forced Vital capacity (FVC) patient was instructed to breathe in with a maximal effort, then exhale as forcefully and rapidly as possible. For Forced Expiratory volume in 1 sec $\left(\mathrm{FEV}_{1}\right)$ : patient was instructed to take full inspiration and then expire forcefully through the mouth piece of the spirometer. For Maximum Voluntary ventilation (MVV): patient was asked to inhale deeply and exhale rapidly in 15 seconds. Peak Expiratory flow (PEF): this occurs very early in the forced expiratory maneuver.

- Interpretation of PFTs is usually based on comparison of patient's data measurements with the reference (predicted) value, the predicted values are based on patient's sex, age, weight and height $^{(126)}$.

- The researcher taught the patient and one of his/her family members the diaphragmatic or pursed lip breathing technique. (According to the group). Then patient's competence was assessed by the researcher. (Do the exercise correctly at least 3 times).

\section{Phase II (Exercise phase):}

- The patients practiced the selected exercises as follows: every week, during the first 3 days the patient practiced the exercise under the supervision of the researcher, and then during the last 3 days he/she practiced the exercise alone without supervision. This was repeated for two weeks.

- The patient practiced the exercise 3times/day (3sessions).

During each session the patient practiced the exercise 4 times / session. Each session was extended from 10-15 minutes.

Group I (Practiced diaphragmatic breathing): the patient was asked to lie down with knees slightly bent or assume fowler position, place one hand on the abdomen and the other on the chest, then inhale slowly and deeply through the nose while letting the abdomen rise more than the chest; Contract the abdominal muscle and begin to exhale through pursed lips, press inward and upward with continuing to exhale. The patient was asked to repeat the exercise for a minute, rest for at least 2 minutes

Group II (Practiced pursed lips breathing): The patient was asked to inhale slowly through abdominal muscles, and then exhale through pursed lips (for a count of six or more). N.B (The expiration should be three times longer than inspiration). 
- An arterial blood gases analysis, Oxygen saturation, and vital signs were measured.

- The prescribed medication was administered (Bronchodilators and/or Expectorants), and a cup of warm fluid was given if needed ${ }^{(8)}$.

\section{Phase III (Post-exercise evaluation phase):}

Pulmonary function tests, arterial blood gases analysis, oxygen saturation and vital signs reassessment were done after completion of the training program (2 weeks) for evaluating the effectiveness of the interventions.

\section{Ethical considerations:}

Approval was obtained to conduct the study from the ethical committee at Faculty of Nursing. Patients' verbal consents were obtained. This approval was obtained after description of the training and its benefits to them. Patients were informed that the participation is voluntary and they can withdraw at any time. Confidentiality of patient data were assured, their names were replaced with a code. Patient privacy was maintained throughout the study. A manual for diaphragmatic breathing and pursed lips breathing was developed based on the review of related literature and given to each patient. Copies of the booklet were kept at the nurses' office to be used later with other patients.

\section{Statistical Analysis}

Statistical analysis was performed using Statistical package for Social Sciences (SPSS) version 16 for windows.

- Number and percentage (No \%) were used for describing and summarizing qualitative data.

- Chi-Square $\left(\chi^{2}\right)$ test was used for comparison between the distributions of two qualitative variables.
- Fisher's exact (FET) test was used for comparison between the distributions of two qualitative variables whenever the $\left(\chi^{2}\right)$ test was not appropriate (> $20 \%$ of the expected cells have expected count $<5$ ).

- $\mathrm{t}$-test was used for comparison between quantitative data in the same group.

- Graphical presentation: Graphs were drawn for data visualization using Microsoft Excel.

*The level of significance selected for this study was $\mathrm{P}$ equal to or less than 0.05 .

\section{Limitations of the study:}

- It was difficult to find patients free from co-morbid diseased as diabetes mellitus, renal disease and congestive heart failure.

- Many times the study procedures were not completed due to rapid turnover of the patients, high admission and limited beds.

- The ABG machine was not found at the chest unit, so it took time to be done.

- Pulse oximeters were not available, so the researcher had to buy it.

\section{Results}

Table (2) shows distribution of biosocio-demographic characteristics for COPD patients. It reveals that the highest percentage $(78.3 \%)$ was among the age group between 50 - 60 years, $73.3 \%$ were in the diaphragmatic group and $83.3 \%$ were in the pursed lips group. The majority of patients in the two studied groups were males $(88.3 \%)$, illiterate $(63.3 \%)$, and lived in rural areas $(66.7 \%)$. There were no statistical significant differences between the two groups.

With reference to COPD onset, table (3) illustrates that, gradual onset was 
encountered among $86.7 \%, 63.3 \%$ of the studied groups respectively, and the majority of the patients among both groups were diagnosed as COPD since one to 9 years. Regarding the smoking condition, almost two thirds of the studied patients reported quitting smoking (61.6\%), distributed as $60 \%$ in the diaphragmatic group and $63.3 \%$ in the pursed lips group, respectively.The longest period of quitting, was more than twelve months in the diaphragmatic group and from six to twelve months in the pursed lips group.

Table (4) shows the comparison of the effect of diaphragmatic breathing versus pursed lips breathing on pulmonary function tests parameters before and after the exercise training. The table portrays differences in pulmonary function tests before and after exercise training within the same group as well as between the two studied groups. A general improvement in all parameters was observed in the two groups after training. However, this improvement did not show significant differences either within the same group or between two groups, except in relation to ERV $(p=0.000 *, p=0.004 *)$ respectively and TV $\left(p=0.003^{*}, p=0.002 *\right)$ respectively which showed statistical significant improvement within the DBT\& PLT groups.

Table (5) clarifies the comparison of the effect of diaphragmatic versus pursed lips breathing on arterial blood gases results before and after exercise training. In relation to arterial blood gases results before and after exercise training among the two studied groups, the blood $\mathrm{PH}$ did not show any statistical significant differences either between the two groups or within each group before and after the exercise training. $\mathrm{PaO}_{2}, \mathrm{PaCO}_{2} \mathrm{Hco}_{3}$ showed significant differences before and after the exercise training within each group, but this improvement did not differ significantly between the two groups. $\left(\mathrm{PaO}_{2}, \mathrm{P}=0.000^{*}\right.$, $\mathrm{P}=0.000 *),\left(\mathrm{PacO}_{2}, \mathrm{P}=0.002 *, \mathrm{P}=0.000 *\right)$, $\left(\mathrm{Hco}_{3}, \mathrm{P}=0.001 *, \mathrm{P}=0.000^{*}\right)$ respectively.
Oxygen saturation $\left(\mathrm{spo}_{2}\right)$ showed significant improvement within the DB group $(\mathrm{t}=$ $7.818, \mathrm{P}=0.000 *)$ and in the PLB group, $(\mathrm{t}=$ 5.849, $\left.\mathrm{P}=0.000^{*}\right)$ meanwhile, this improvement did not differ significantly from one group to another.

Table (6) compares the vital signs before and after the exercises training within each group and between the two studied groups. Body temperature did not show any significant difference either between groups or in the same group before and after exercise training. The pulse rate tended to decrease after training in both groups with no statistical significant differences between the studied groups. The same holds true for respiratory rate, however patients who practiced PLB only showed significant difference before and after the exercise $\left(\mathrm{t}=2.588, \mathrm{P}=0.012^{*}\right)$. Systolic and diastolic blood pressure did not show any significant change either in the same group or between two studied groups.

Table (7) reveals the staging of COPD before and after exercise training among the two studied groups. A general improvement could be observed in two groups after training. A moderate COPD stage was most commonly encountered among the two groups, representing $60 \%, 70$, of the diaphragmatic and pursed lips groups respectively, before the exercise training and $86.7 \%, 93.3 \%$ respectively, after the exercise training. Statistical significant differences could be detected within the two groups since $\mathrm{FET}=5.455, \mathrm{P}=0.019 *$ in the DB group and 5.454, and 0.018* respectively, in the PLB group.

\section{Discussion}

Chronic obstructive pulmonary disease (COPD) is a major cause of disability that dramatically alters the well being of the patients as well as their quality of life. ${ }^{(35)}$ Historically, the management of COPD has focused on strategies to prevent further deterioration of lung function, such as smoking cessation and standard medical treatment to try to improve symptoms. 
There is now increased awareness that interventions are needed to improve the patient's functional abilities, and to introduce strategies to help them cope with their condition. So, a comprehensive care program including pulmonary rehabilitation will be beneficial for the patient and his family $^{(27-36)}$.

In the present study, it was found that, most of the patient's age ranged between 5060 years old. This could be because the occurrence of COPD increases with age as the airspaces gets bigger and lose their elasticity and results in less area for gases exchange, also the strength of the respiratory muscles (the diaphragm and intercostal muscles) decreases. This finding is congruent with the result of $\mathrm{Kim}$ et al $(2005)^{(37)}$ who conducted a Korean survey and concluded that, the prevalence of COPD was $17.2 \%$ among subjects over 45 years of age. $\operatorname{Stang}^{(38)}$ reported that 15.3 million people who are over 40 years of age in the United States have COPD.

The present study indicated that, the majority of the subjects were males. The difference in COPD between men and women is mostly due to differences in smoking habits and culture where smoking among women is still less compared to smoking among men and it is not culturally prevailing. This is supported by a study by Zhong et al $(2007)^{(39)}$ in China who stated that, the prevalence of COPD was significantly higher in men than in women. Also Silverman $(2000)^{(40)}$ found that, men have higher prevalence rates of COPD than women, which has been attributed to the historically higher rates of cigarette smoking in men. However, the increased rates of cigarette smoking in females in the last several decades have been associated with steadily increasing rates of COPD in women.

In relation to the educational level, the current study showed that, the majority of the subjects were illiterate. These results are similar to the results of Ansari et al $(2005)^{(41)}$ who studied the impact of pharmaceutical intervention on inhalation technique, and found that $80 \%$ of the total COPD patients, were illiterate. Johnson et al $(2011)^{(42)}$ reported that the majority of the subjects were illiterate and of low socioeconomic status. In this study the majority of the subjects were smokers either having a history of smoking (Quitters) or currently smoking cigarette, Hubble bubbles, drugs, or combinations of these. This is supported by a study by Lindbirg $(2005)^{(43)}$ who emphasized that the prevalence of COPD was associated with the age and smoking.

This association between age, gender, illiteracy, smoking and COPD could be due to the lack of scientific information about the hazards of smoking and its relation to morbidity and could be due to lack of resources or education programs about smoking cessation.

About one fifth of the present study subjects were non smokers but they developed COPD as they were exposed to second hand smoke. This is in line with a study by $\mathrm{Ekici}^{(44)}$ that included case-control study of 596 never smoking women in Turkey and revealed that prevalence of COPD due to biomass smoke to be $23 \%$. Prikle et al $(2006)^{(45)}$ studied the exposure of nonsmokers in the United state population to secondhand smoke, and concluded that the exposure of nonsmokers to secondhand smoke represents an important public health concern.

Expiratory flow limitation is the hallmark of COPD, which promotes air trapping and dynamic lung hyperinflation, and appears to be the main cause of exertional breathlessness and exercise intolerance. In this context, the nurse has a vital role in teaching the patients the adaptive breathing techniques as PLB and DB that help control respiratory rate and breathing patterns, thus decreasing air trapping. These techniques also help to decrease the work of breathing and improve the position and function of the respiratory muscles $^{(46)}$. 
Pulmonary function tests (PFTs) are the primary diagnostic tools for COPD. These tests demonstrate characteristic abnormalities in lung function confirm or support the diagnosis of COPD and give some idea of the degree of impairment and prognosis, so the nurse should encourage patients to perform PFTs on a routine basis, to identify any rapid decline in (FEV1) and to improve quality of life ${ }^{(47)}$.

Regarding pulmonary function tests changes following the exercise training, the present study revealed that only the $\left(\mathrm{V}_{\mathrm{T}}\right)$ and ERVshowed significant changes after exercise training in the two groups. Other parameters as the VC, FVC, and FEV in one second, Maximum voluntary ventilation) did not demonstrate significant changes after the exercise training. These results are in accordance with Avanji (2011) ${ }^{(48)}$ who assessed the effect of pursed lips breathing on ventilation and activity of daily living in patients with COPD, and concluded that (FEV1\%) and (FVC) did not change after the PLB. Spahija $(2005)^{(49)}$, found (PLB) promoted larger $\mathrm{V}_{\mathrm{T}}$ values. The same results were confirmed by Vitacca et al (1998) $)^{(50)}$ who proved that deep diaphragmatic breathing (DB) was associated with a significant increase in $\mathrm{V}_{\mathrm{T}}$. Jyothy $2011^{(51)}$ illustrated that deep breathing exercise showed statistical significant improvement the pulmonary function of patients with chronic airflow limitation. Also Gosselink reported that $\mathrm{TV}$, respiratory frequency, and duty cycle did not change significantly after DB exercises ${ }^{(52)}$.

Moreover, the present study revealed that, there were improvements in $\left(\mathrm{pao}_{2}\right)$, $\left(\mathrm{spo}_{2}\right)$ and decrease in $\left(\mathrm{pco}_{2}\right)$, following the exercise training for both studied groups. This lies in agreement with Hem et al $(2004)^{(53)}$ who stated that PLB and DB exercises produce significant increase in $\mathrm{PaO}_{2}$ and $\mathrm{Spo}_{2}$ and a significant decrease in $\mathrm{PaCO}_{2}$. These results are also parallel to Fregonezi ${ }^{(54)}$ who found significant increase in $\mathrm{PaO}_{2}, \mathrm{SpO}_{2}$ and a significant decrease in $\mathrm{PaCO}_{2}$, following the PLB. Also, Dechman et al (2004) $)^{(55),}$ emphasized that diaphragmatic breathing can lead to improvements in ventilation reflected as decreases in $\mathrm{CO}_{2}$ levels or improvements in oxygenation.

The increase in $\mathrm{SpO}_{2}$ during PLB could be because the increased duration of expiration and consequent increase in tidal volume leads to homogenous lung emptying, thereby maintaining the intrabronchial pressure and favoring both gas exchange and ventilation. This finding is in contradiction with Roa et al (1999) ${ }^{(56)}$ who reported that pursed lips breathing induced a minimal increase in $\mathrm{SpO}_{2}$ that was not statistically significant as the patients in that study practiced pursed lips breathing during exercises, not at rest .

Vital sign monitoring is a fundamental component of nursing care. It provides data that reflect the status of several body systems. ${ }^{(54)}$ Ramos et al (2009) ${ }^{(57)}$ stated that, pursed lips breathing produced significant changes in heart rate, respiratory rate and $\mathrm{SpO}_{2}$, and did not alter blood pressure in subjects with COPD. A study conducted by Kulur(2009) ${ }^{(58)}$ to assess the effect of diaphragmatic breathing on heart rate variability in ischemic heart disease with diabetes, concluded that, the regular practice of diaphragmatic breathing significantly improves heart rate variability. This is in congruent with the findings of the present study as there was a significant decrease in heart rate following exercise training among both subjects, however the pursed lips training showed significant changes in respiratory rate, and no changes in blood pressure measurements among both groups. The decrease in RR during PLB is possibly related to better control over the respiratory cycles and increased duration of expiration, thus leading to a higher TV.

\section{Conclusion}

Pulmonary rehabilitation including pursed lips breathing and diaphragmatic breathing is an integral part of the clinical 
management and health maintenance of patients with chronic respiratory disease. These exercises are known to improve quality of life, exercise tolerance, relieve fatigue, improve emotional function and enhance patients' sense of control over their condition $^{(164,165)}$.

The current study aimed to assess the effect of diaphragmatic breathing and pursed lips breathing on pulmonary functions of COPD patients, and to compare between the effects of diaphragmatic breathing training and pursed-lips breathing on these patients' pulmonary functions.

Based on the results of this study, it can be concluded that pursed lips breathing and diaphragmatic breathing can lead to significant changes in the variables of the breathing pattern in patients with COPD, ventilation became more efficient and the arterial blood gases and oxygen saturation improved as follows:

- Regarding pulmonary function parameters there were only significant changes in tidal volume and expiratory reserve volume after the exercise training in both studied groups.

- There were significant improvements in $\mathrm{PaO}_{2}, \mathrm{PCO}_{2}$, $\mathrm{SPO}_{2}$ results within each of the studied groups.

- Vital signs assessment following the exercise training showed significant decrease in heart rate in the two studied groups, PL group showed significant change in respiratory rate. No changes in blood pressure measurements could be detected either within or between the two studied groups.

\section{Recommendations}

From the results of this study, the following recommendations are suggested:

\section{A: For the patients:}

- Greater emphasis should be placed on patient education regarding pulmonary rehabilitation.

- Written instruction plans need to be provided for COPD patients for daily self management which includes diaphragmatic and pursed lips breathing to be followed at home.

- Pulmonary rehabilitation centers need to be established in primary health care settings for COPD patients.

- Pulmonary function tests and arterial blood gases should routinely checked for all COPD patients on their hospital admission and discharge.

\section{B: Suggestions for further studies:}

- Assessing nurse's knowledge regarding pulmonary rehabilitation and its application.

- Assessing the effect of pulmonary rehabilitation programs on patient's progression and period of hospitalization at major teaching, and Ministry of Health hospitals.

- Determining the actual prevalence of COPD in Egypt. 
Table (2): Distribution of the socio-demographic characteristics of the studied patients.

\begin{tabular}{|c|c|c|c|c|c|c|c|}
\hline \multirow{3}{*}{$\begin{array}{l}\text { Socio-demographic } \\
\text { characteristics }\end{array}$} & \multicolumn{4}{|c|}{ Study group $(\mathrm{No}=60)$} & \multirow{2}{*}{\multicolumn{2}{|c|}{ Total }} & \multirow{3}{*}{$\begin{array}{c}\text { Significance } \\
\text { test }\end{array}$} \\
\hline & \multicolumn{2}{|c|}{$\begin{array}{c}\text { Diaphragmatic } \\
\text { Group }\end{array}$} & \multicolumn{2}{|c|}{$\begin{array}{l}\text { Pursed lips } \\
\text { Group }\end{array}$} & & & \\
\hline & No=30 & $\%$ & No $=30$ & $\%$ & No $=60$ & $\%$ & \\
\hline $\begin{array}{l}\text { Age (years) } \\
20-29\end{array}$ & 0 & 0 & 0 & 0 & 0 & 0 & \\
\hline $30-39$ & 0 & 0 & 0 & 0 & 0 & 0 & $\mathrm{FET}=0.884$ \\
\hline $40-49$ & 8 & 26.7 & 5 & 16.7 & 13 & 21.7 & $\mathrm{P}=0.347$ \\
\hline $50-60$ & 22 & 73.3 & 25 & 83.3 & 47 & 78.3 & \\
\hline Total & 30 & 100 & 30 & 100 & 60 & 100 & \\
\hline $\begin{array}{l}\text { Sex } \\
\text { Male }\end{array}$ & 26 & 86.7 & 27 & 90 & 53 & 88.3 & $\mathrm{FET}=0.161$ \\
\hline Female & 4 & 13.3 & 3 & 10 & 7 & 11.7 & $\mathrm{P}=0.688$ \\
\hline Total & 30 & 100 & 30 & 100 & 60 & 100 & \\
\hline $\begin{array}{l}\text { Level of education } \\
\text { Illiterate }\end{array}$ & 21 & 70 & 17 & 56.7 & 38 & 63.3 & \\
\hline $\begin{array}{l}\text { Read\& write+ Primary } \\
\text { education }\end{array}$ & 9 & 30 & 10 & 33.3 & 19 & 31.7 & $\mathrm{FET}=3.498$ \\
\hline Preparatory+ Secondary & 0 & 0 & 2 & 6.7 & 2 & 3.3 & $\mathrm{P}=0.624$ \\
\hline Diploma & 0 & 0 & 1 & 3.3 & 1 & 1.7 & \\
\hline University & 0 & 0 & 0 & 0 & 0 & 0 & \\
\hline Total & 30 & 100 & 30 & 100 & 60 & 100 & \\
\hline
\end{tabular}


Table (3): Distribution of medical data of the studied patients.

\begin{tabular}{|c|c|c|c|c|c|c|c|}
\hline \multirow{3}{*}{ Medical data } & \multicolumn{4}{|c|}{ Study group $(\mathrm{No}=60)$} & \multirow{2}{*}{\multicolumn{2}{|c|}{ Total }} & \multirow{3}{*}{$\begin{array}{c}\text { Significance } \\
\text { test }\end{array}$} \\
\hline & \multicolumn{2}{|c|}{$\begin{array}{l}\text { Diaphragmatic } \\
\text { Group }\end{array}$} & \multicolumn{2}{|c|}{$\begin{array}{l}\text { Pursed lips } \\
\text { Group }\end{array}$} & & & \\
\hline & $\begin{array}{c}\text { No= } \\
30\end{array}$ & $\%$ & $\begin{array}{c}\text { No= } \\
30\end{array}$ & $\%$ & $\begin{array}{c}\mathrm{No}= \\
60\end{array}$ & $\%$ & \\
\hline $\begin{array}{l}\text { Onset of the disease } \\
\text { Gradual }\end{array}$ & 26 & 86.7 & 19 & 63.3 & 45 & 75 & \multirow[t]{3}{*}{$\begin{array}{c}\mathrm{FET}=4.355 \\
\mathrm{P}=0.037 *\end{array}$} \\
\hline Sudden & 4 & 13.3 & 11 & 36.7 & 15 & 25 & \\
\hline Total & 30 & 100 & 30 & 100 & 60 & 100 & \\
\hline $\begin{array}{l}\text { Since How long the } \\
\text { disease started (years) } \\
1-9\end{array}$ & 20 & 666 & 22 & 73.3 & 42 & 70 & \multirow[t]{4}{*}{$\begin{array}{c}\mathrm{FET}=9.369 \\
\mathrm{P}=0.053\end{array}$} \\
\hline $10-19$ & $\frac{20}{8}$ & 26.7 & $\frac{22}{8}$ & 26.7 & 16 & 26.7 & \\
\hline $20-30$ & 2 & 6.7 & 0 & 0 & 2 & 3.3 & \\
\hline Total & 30 & 100 & 30 & 100 & 60 & 100 & \\
\hline $\begin{array}{l}\text { Smoking Condition } \\
\text { Non smoker }\end{array}$ & 3 & 10 & 4 & 13.3 & 7 & 11.7 & \multirow[t]{5}{*}{$\begin{array}{c}\mathrm{FET}=1.837 \\
\mathrm{P}=0.607\end{array}$} \\
\hline Smoker & 5 & 16.7 & 5 & 16.7 & 10 & 16.7 & \\
\hline Quitter & 18 & 60 & 19 & 63.3 & 37 & 61.6 & \\
\hline Passive smoker & 4 & 13.3 & 2 & 6.7 & 6 & 10 & \\
\hline Total & 30 & 100 & 30 & 100 & 60 & 100 & \\
\hline $\begin{array}{l}\text { Type of smoking } \\
\text { Cigarette }\end{array}$ & 3 & 60 & 2 & 40 & 5 & 50 & \multirow[t]{6}{*}{$\begin{array}{c}\mathrm{FET}=2.133 \\
\mathrm{P}=0.344\end{array}$} \\
\hline $\begin{array}{l}\text { Cigarette }+ \text { Hubble } \\
\text { bubble }(\text { shisha })\end{array}$ & 0 & 0 & 1 & 20 & 1 & 10 & \\
\hline Cigarette +drugs & 1 & 20 & 1 & 20 & 2 & 20 & \\
\hline $\begin{array}{l}\text { Cigarette+Hubble } \\
\text { bubble }+ \text { drugs }\end{array}$ & 1 & 20 & 1 & 20 & 2 & 20 & \\
\hline Total & 5 & 100 & 5 & 100 & 10 & 100 & \\
\hline$*^{2}$ Not applicable & 25 & & 25 & & 50 & & \\
\hline $\begin{array}{l}\text { Duration of quitting } \\
\text { (month) }\end{array}$ & & & & & & & \multirow[t]{6}{*}{$\begin{array}{c}\mathrm{FET}=6.311 \\
\mathrm{P}=0.177\end{array}$} \\
\hline$\ldots<6$ & 6 & 33.3 & 5 & 26.3 & 11 & 29.7 & \\
\hline $6-12$ & 3 & 16.7 & 9 & 47.4 & 12 & 32.5 & \\
\hline..$>12$ & 9 & 50 & 5 & 26.3 & 14 & 37.8 & \\
\hline Total & 18 & 100 & 19 & 100 & 37 & 100 & \\
\hline$*^{3}$ Not applicable & 12 & & 11 & & 23 & & \\
\hline
\end{tabular}


Table (4): Comparison of the effect of diaphragmatic breathing versus pursed lips breathing on pulmonary function tests parameters before and after exercise training.

\begin{tabular}{|c|c|c|c|c|c|c|}
\hline \multirow{4}{*}{$\begin{array}{l}\text { Pulmonary } \\
\text { function test } \\
\text { parameters }\end{array}$} & \multicolumn{4}{|c|}{ Study group $(\mathrm{No}=60)$} & \multirow{2}{*}{\multicolumn{2}{|c|}{$\begin{array}{c}\text { Significance } \\
\text { test }\end{array}$}} \\
\hline & \multicolumn{2}{|c|}{$\begin{array}{c}\text { Diaphragmatic group } \\
(\mathrm{No}=30)\end{array}$} & \multicolumn{2}{|c|}{$\begin{array}{l}\text { Pursed lips group } \\
(\mathrm{No}=\mathbf{3 0})\end{array}$} & & \\
\hline & Before & After & Before & After & & \\
\hline & Mean \pm SD & Mean \pm SD & Mean \pm SD & Mean \pm SD & Before & After \\
\hline $\begin{array}{l}\text { Predicted } \\
\text { VC }\end{array}$ & $70.92 \pm 11.428$ & $74.24 \pm 11.636$ & $70.47 \pm 9.834$ & $74.05 \pm 8.528$ & $\mathrm{t}=0.115$ & $\mathrm{t}=0.050$ \\
\hline $\begin{array}{l}\text { Significance } \\
\text { test }\end{array}$ & \multicolumn{2}{|c|}{$\begin{array}{l}\mathrm{t}=0.788 \\
\mathrm{P}=0.434\end{array}$} & \multicolumn{2}{|c|}{$\begin{array}{l}\mathrm{t}=1.069 \\
\mathrm{P}=0.289\end{array}$} & $\mathrm{P}=0.909$ & $\mathrm{P}=0.960$ \\
\hline $\begin{array}{l}\text { Predicted } \\
\text { FVC }\end{array}$ & $69.54 \pm 10.819$ & $73.01 \pm 10.941$ & $69.92 \pm 9.854$ & $73.75 \pm 8.508$ & $\mathrm{t}=0.100$ & $\mathrm{t}=0.207$ \\
\hline $\begin{array}{l}\text { Significance } \\
\text { test }\end{array}$ & \multicolumn{2}{|c|}{$\begin{array}{l}\mathrm{t}=0.873 \\
\mathrm{P}=0.386\end{array}$} & \multicolumn{2}{|c|}{$\begin{array}{l}\mathrm{t}=1.143 \\
\mathrm{P}=0.258\end{array}$} & $\mathrm{P}=0.921$ & $\mathrm{P}=0.836$ \\
\hline $\begin{array}{l}\text { Predicted } \\
\text { FEV1 }\end{array}$ & $62.70 \pm 14.619$ & $67.50 \pm 13.256$ & $60.86 \pm 13.272$ & $65.74 \pm 10.756$ & $\mathrm{t}=0.362$ & $\mathrm{t}=0.403$ \\
\hline $\begin{array}{l}\text { Significance } \\
\text { test }\end{array}$ & \multicolumn{2}{|c|}{$\begin{array}{l}\mathrm{t}=0.943 \\
\mathrm{P}=0.349\end{array}$} & \multicolumn{2}{|c|}{$\begin{array}{l}\mathrm{t}=1.112 \\
\mathrm{P}=0.271\end{array}$} & $\mathrm{P}=0.719$ & $\mathrm{P}=0.688$ \\
\hline $\begin{array}{l}\text { Predicted } \\
\text { FEV1\% }\end{array}$ & $63.92 \pm 10.192$ & $66.88 \pm 8.789$ & $62.04 \pm 9.716$ & $65.39 \pm 8.129$ & $\mathrm{t}=0.517$ & $\mathrm{t}=0.481$ \\
\hline $\begin{array}{l}\text { Significance } \\
\text { test }\end{array}$ & \multicolumn{2}{|c|}{$\begin{array}{l}t=0.854 \\
P=0.397\end{array}$} & \multicolumn{2}{|c|}{$\begin{array}{l}\mathrm{t}=1.029 \\
\mathrm{P}=0.308\end{array}$} & $\mathrm{P}=0.607$ & $\mathrm{P}=0.632$ \\
\hline $\begin{array}{l}\text { Predicted } \\
\text { PEF }\end{array}$ & $55.47 \pm 18.055$ & $60.80 \pm 16.065$ & $57.84 \pm 13.817$ & $62.48 \pm 13.119$ & $\mathrm{t}=0.407$ & $\mathrm{t}=0.315$ \\
\hline $\begin{array}{l}\text { Significance } \\
\text { test }\end{array}$ & \multicolumn{2}{|c|}{$\begin{array}{l}\mathrm{t}=0.855 \\
\mathrm{P}=0.396\end{array}$} & \multicolumn{2}{|c|}{$\begin{array}{l}\mathrm{t}=0.943 \\
\mathrm{P}=0.349\end{array}$} & $\mathrm{P}=0.686$ & $\mathrm{P}=0.754$ \\
\hline $\begin{array}{l}\text { Predicted } \\
\text { MVV }\end{array}$ & $62.57 \pm 11.131$ & $72.94 \pm 94.002$ & $54.74 \pm 11.018$ & $60.70 \pm 10.346$ & $\mathrm{t}=0.949$ & $\mathrm{t}=0.477$ \\
\hline $\begin{array}{l}\text { Significance } \\
\text { test }\end{array}$ & \multicolumn{2}{|c|}{$\begin{array}{l}\mathrm{t}=0.541 \\
\mathrm{P}=0.591\end{array}$} & \multicolumn{2}{|c|}{$\begin{array}{l}\mathrm{t}=1.526 \\
\mathrm{P}=0.132\end{array}$} & $\mathrm{P}=0.346$ & $\mathrm{P}=0.635$ \\
\hline $\begin{array}{l}\text { Predicted } \\
\text { ERV }\end{array}$ & $\begin{array}{c}700.00 \pm 78.78 \\
4\end{array}$ & $\begin{array}{c}843.33 \pm 87.82 \\
2\end{array}$ & $\begin{array}{c}710.00 \pm 117.7 \\
37\end{array}$ & $\begin{array}{c}831.67 \pm 102.9 \\
59\end{array}$ & \multirow{2}{*}{$\begin{array}{l}\mathrm{t}=0.279 \\
\mathrm{P}=0.781\end{array}$} & \multirow{2}{*}{$\begin{array}{l}t=0.335 \\
P=0.739\end{array}$} \\
\hline $\begin{array}{l}\text { Significance } \\
\text { test }\end{array}$ & \multicolumn{2}{|c|}{$\begin{aligned} \mathrm{t} & =4.712 \\
\mathrm{P} & =0.000 *\end{aligned}$} & \multicolumn{2}{|c|}{$\begin{aligned} \mathrm{t} & =3.019 \\
\mathrm{P} & =0.004^{*}\end{aligned}$} & & \\
\hline Predicted $V_{T}$ & $\begin{array}{c}408.33 \pm 63.08 \\
6\end{array}$ & $\begin{array}{c}465.00 \pm 37.48 \\
6\end{array}$ & $\begin{array}{c}400.00 \pm 55.70 \\
9\end{array}$ & $\begin{array}{c}455.00 \pm 35.59 \\
8\end{array}$ & \multirow{2}{*}{$\begin{array}{l}\mathrm{t}=0.384 \\
\mathrm{P}=0.702\end{array}$} & \multirow{2}{*}{$\begin{array}{l}t=0.749 \\
P=0.457\end{array}$} \\
\hline $\begin{array}{l}\text { Significance } \\
\text { test }\end{array}$ & \multicolumn{2}{|c|}{$\begin{aligned} \mathrm{t} & =3.086 \\
\mathrm{P} & =0.003^{*}\end{aligned}$} & \multicolumn{2}{|c|}{$\begin{aligned} \mathrm{t} & =3.299 \\
\mathrm{P} & =0.002^{*}\end{aligned}$} & & \\
\hline $\begin{array}{l}\text { - VC: Vital cap } \\
\text { - FVC: Forced } \\
\text { - FEV1: Forcec } \\
\text { - FEV1\%: FEV } \\
\text { - PEF: Peak Ex }\end{array}$ & $\begin{array}{l}\text { acity. } \\
\text { Vital capacity. } \\
\text { l expiratory volu } \\
\text { 1/FVC ratio. } \\
\text { piratory flow. }\end{array}$ & $\begin{array}{ll} & \text { - MVV } \\
& - \text { ERV } \\
\text { sec. } & -V_{\mathrm{T}}: \\
& - \text { SD: } \\
& \text { - "Sign }\end{array}$ & $\begin{array}{l}\text { Maximum Volunt } \\
\text { Expiratory reserve } \\
\text { dal volume. } \\
\text { andard deviation. } \\
\text { icant difference at }\end{array}$ & $\begin{array}{l}\begin{array}{l}\text { ary ventilation } \\
\text { volume. }\end{array} \\
\text { P level } \leq 0.05 .\end{array}$ & & \\
\hline
\end{tabular}


Table (5): Comparison of the effect of diaphragmatic versus pursed lips breathing on Arterial blood gases results before and after the exercise training.

\begin{tabular}{|c|c|c|c|c|c|c|}
\hline \multirow{4}{*}{$\begin{array}{l}\text { Arterial } \\
\text { blood gases } \\
\text { parameters }\end{array}$} & \multicolumn{4}{|c|}{ Study group $(\mathrm{No}=60)$} & \multirow{2}{*}{\multicolumn{2}{|c|}{ Significance test }} \\
\hline & \multicolumn{2}{|c|}{$\begin{array}{c}\text { Diaphragmatic } \\
\text { Group }(\mathrm{No}=\mathbf{3 0})\end{array}$} & \multicolumn{2}{|c|}{$\begin{array}{c}\text { Pursed lips } \\
\text { group }(\mathrm{No}=30)\end{array}$} & & \\
\hline & Before & After & Before & After & \multirow{2}{*}{ Before } & \multirow{2}{*}{ After } \\
\hline & Mean \pm SD & Mean \pm SD & Mean \pm SD & Mean \pm SD & & \\
\hline $\mathrm{PH}$ & $7.15 \pm 1.024$ & $7.46 \pm 181.000$ & $7.28 \pm 735.000$ & $7.40 \pm 064.000$ & \multirow{2}{*}{$\begin{array}{l}\mathrm{t}=1.267 \\
\mathrm{p}=0.210\end{array}$} & \multirow{2}{*}{$\begin{array}{l}\mathrm{t}=0.394 \\
\mathrm{p}=0.695\end{array}$} \\
\hline $\begin{array}{l}\text { Significance } \\
\text { test }\end{array}$ & \multicolumn{2}{|c|}{$\begin{array}{l}\mathrm{t}=1.399 \\
\mathrm{p}=0.167\end{array}$} & \multicolumn{2}{|c|}{$\begin{array}{l}\mathrm{t}=0.852 \\
\mathrm{p}=0.398\end{array}$} & & \\
\hline $\mathrm{PaO}_{2}$ & $64.53 \pm 11.008$ & $81.28 \pm 8.665$ & $66.65 \pm 10.684$ & $82.56 \pm 9.762$ & \multirow{2}{*}{$\begin{array}{l}\mathrm{t}=0.536 \\
\mathrm{p}=0.594\end{array}$} & \multirow{2}{*}{$\begin{array}{l}\mathrm{t}=0.378 \\
\mathrm{p}=0.706\end{array}$} \\
\hline $\begin{array}{l}\text { Significance } \\
\text { test }\end{array}$ & \multicolumn{2}{|c|}{$\begin{array}{c}\mathrm{t}=4.664 \\
\mathrm{p}=0.000 *\end{array}$} & \multicolumn{2}{|c|}{$\begin{array}{l}\mathrm{t}=4.260 \\
\mathrm{p}=0.000^{*}\end{array}$} & & \\
\hline $\mathrm{PacO}_{2}$ & $55.68 \pm 9.682$ & $44.89 \pm 8.066$ & $54.41 \pm 8.960$ & $41.66 \pm 5.720$ & \multirow{2}{*}{$\begin{array}{l}\mathrm{t}=0.372 \\
\mathrm{p}=0.711\end{array}$} & \multirow{2}{*}{$\begin{array}{l}\mathrm{t}=1.281 \\
\mathrm{p}=0.205\end{array}$} \\
\hline $\begin{array}{l}\text { Significance } \\
\text { test }\end{array}$ & \multicolumn{2}{|c|}{$\begin{array}{l}\mathrm{t}=3.331 \\
\mathrm{p}=0.002 *\end{array}$} & \multicolumn{2}{|c|}{$\begin{array}{l}\mathrm{t}=4.757 \\
\mathrm{p}=0.000^{*}\end{array}$} & & \\
\hline $\mathrm{HcO}_{3}$ & $33.75 \pm 5.501$ & $28.12 \pm 3.370$ & $33.58 \pm 5.373$ & $27.53 \pm 2.986$ & \multirow{2}{*}{$\begin{array}{l}\mathrm{t}=0.082 \\
\mathrm{p}=0.935\end{array}$} & \multirow{2}{*}{$\begin{array}{l}\mathrm{t}=0.503 \\
\mathrm{p}=0.617\end{array}$} \\
\hline $\begin{array}{l}\text { Significance } \\
\text { test }\end{array}$ & \multicolumn{2}{|c|}{$\begin{aligned} t & =3.476 \\
p & =0.001 *\end{aligned}$} & \multicolumn{2}{|c|}{$\begin{array}{l}t=3.965 \\
p=0.000 *\end{array}$} & & \\
\hline Spo2 & $94.93 \pm 1.202$ & $\begin{array}{c}98.00 \pm 947.00 \\
0\end{array}$ & $94.87 \pm 1.613$ & $97.87 \pm 1.196$ & \multirow{2}{*}{$\begin{array}{l}\mathrm{t}=0.130 \\
\mathrm{p}=0.897\end{array}$} & \multirow{2}{*}{$\begin{array}{l}t=0.341 \\
p=0.734\end{array}$} \\
\hline $\begin{array}{l}\text { Significance } \\
\text { test }\end{array}$ & \multicolumn{2}{|c|}{$\begin{array}{l}t=7.818 \\
p=0.000^{*}\end{array}$} & \multicolumn{2}{|c|}{$\begin{array}{l}t=5.849 \\
p=0.000^{*}\end{array}$} & & \\
\hline
\end{tabular}


Table (6): Comparison of the effect of diaphragmatic versus pursed lips breathing on Vital signs before and after exercise training.

\begin{tabular}{|c|c|c|c|c|c|c|}
\hline \multirow{4}{*}{ Vital signs } & \multicolumn{4}{|c|}{ Study group $(\mathrm{No}=60)$} & \multirow{2}{*}{\multicolumn{2}{|c|}{ Significance test }} \\
\hline & \multicolumn{2}{|c|}{$\begin{array}{c}\text { Diaphragmatic } \\
\text { Group }(\text { No }=30)\end{array}$} & \multicolumn{2}{|c|}{$\begin{array}{c}\text { Pursed lips } \\
\text { group(No= 30) }\end{array}$} & & \\
\hline & Before & After & Before & After & \multirow{2}{*}{ Before } & \multirow{2}{*}{ After } \\
\hline & Mean \pm SD & Mean \pm SD & Mean \pm SD & Mean \pm SD & & \\
\hline $\begin{array}{l}\text { Temperature } \\
\left({ }^{\circ} \mathrm{C}\right)\end{array}$ & $\begin{array}{c}37.00 \\
\pm 131.000\end{array}$ & $\begin{array}{c}37.00 \pm \\
141.000\end{array}$ & $\begin{array}{c}37.00 \pm \\
087.000\end{array}$ & $37.00 \pm 094.000$ & $\mathrm{t}=0.091$ & $\mathrm{t}=0.078$ \\
\hline $\begin{array}{l}\text { Significance } \\
\text { test }\end{array}$ & \multicolumn{2}{|c|}{$\begin{array}{l}\mathrm{t}=0.022 \\
\mathrm{P}=0.982\end{array}$} & \multicolumn{2}{|c|}{$\begin{array}{l}\mathrm{t}=0.026 \\
\mathrm{P}=0.979\end{array}$} & $P=0.928$ & $P=0.938$ \\
\hline Pulse(b/m) & $76.00 \pm 2.156$ & $74.00 \pm 1.944$ & $76.00 \pm 1.956$ & $75.00 \pm 1.927$ & \multirow{2}{*}{$\begin{array}{l}\mathrm{t}=0.543 \\
\mathrm{P}=0.589\end{array}$} & \multirow{2}{*}{$\begin{array}{l}\mathrm{t}=1.517 \\
\mathrm{P}=0.135\end{array}$} \\
\hline $\begin{array}{l}\text { Significance } \\
\text { test }\end{array}$ & \multicolumn{2}{|c|}{$\begin{aligned} \mathrm{t} & =3.025 \\
\mathrm{P} & =0.004 *\end{aligned}$} & \multicolumn{2}{|c|}{$\begin{aligned} \mathrm{t} & =2.257 \\
\mathrm{P} & =0.028^{*}\end{aligned}$} & & \\
\hline $\begin{array}{l}\text { Respiration } \\
(\mathrm{c} / \mathrm{m})\end{array}$ & $20.00 \pm 1.582$ & $19.00 \pm 1.407$ & $20.00 \pm 1.339$ & $18.00 \pm 1.401$ & \multirow{2}{*}{$\begin{array}{l}\mathrm{t}=0.597 \\
\mathrm{P}=0.553\end{array}$} & \multirow{2}{*}{$\begin{array}{l}\mathrm{t}=0.155 \\
\mathrm{P}=0.877\end{array}$} \\
\hline $\begin{array}{l}\text { Significance } \\
\text { test }\end{array}$ & \multicolumn{2}{|c|}{$\begin{array}{l}\mathrm{t}=1.934 \\
\mathrm{P}=0.058\end{array}$} & \multicolumn{2}{|c|}{$\begin{aligned} \mathrm{t} & =2.588 \\
\mathrm{P} & =0.012 *\end{aligned}$} & & \\
\hline \begin{tabular}{|l} 
Systolic \\
blood \\
pressure \\
$(\mathrm{mmHg})$
\end{tabular} & $119.00 \pm 3.400$ & $118.00 \pm 3.600$ & $118.00 \pm 2.200$ & $118.00 \pm 2.100$ & \multirow[t]{2}{*}{$\begin{array}{c}t=0.564 \\
P=0.0575\end{array}$} & \multirow[t]{2}{*}{$\begin{array}{l}\mathrm{t}=0.553 \\
\mathrm{P}=0.582\end{array}$} \\
\hline $\begin{array}{l}\text { Significance } \\
\text { test }\end{array}$ & \multicolumn{2}{|c|}{$\begin{array}{l}\mathrm{t}=0.073 \\
\mathrm{P}=0.942\end{array}$} & \multicolumn{2}{|c|}{$\begin{array}{l}\mathrm{t}=0.119 \\
\mathrm{P}=0.906\end{array}$} & & \\
\hline $\begin{array}{l}\text { Diastolic } \\
\text { blood } \\
\text { pressure } \\
(\mathrm{mmHg})\end{array}$ & $79.00 \pm 2.800$ & $78.00 \pm 2.900$ & $77.00 \pm 1.800$ & $77.00 \pm 1.700$ & \multirow[t]{2}{*}{$\begin{array}{l}\mathrm{t}=1.387 \\
\mathrm{P}=0.171\end{array}$} & \multirow[t]{2}{*}{$\begin{array}{l}\mathrm{t}=1.288 \\
\mathrm{P}=0.203\end{array}$} \\
\hline $\begin{array}{l}\text { Significance } \\
\text { test }\end{array}$ & \multicolumn{2}{|c|}{$\begin{array}{l}\mathrm{t}=0.162 \\
\mathrm{P}=0.872\end{array}$} & \multicolumn{2}{|c|}{$\begin{array}{l}\mathrm{t}=0.146 \\
\mathrm{P}=0.884\end{array}$} & & \\
\hline
\end{tabular}


Table (7): Stages of chronic obstructive pulmonary disease before and after exercises training among the studied groups.

\begin{tabular}{|c|c|c|c|c|c|c|c|c|c|c|}
\hline \multirow{4}{*}{ COPD stages } & \multicolumn{8}{|c|}{ Study group $(\mathrm{No}=60)$} & \multirow{2}{*}{\multicolumn{2}{|c|}{ Significance test }} \\
\hline & \multicolumn{4}{|c|}{$\begin{array}{l}\text { Diaphragmatic } \\
\text { Group }(\text { No }=30)\end{array}$} & \multicolumn{4}{|c|}{$\begin{array}{c}\text { Pursed lips } \\
\text { group }(\mathrm{No}=30)\end{array}$} & & \\
\hline & \multicolumn{2}{|c|}{ Before } & \multicolumn{2}{|c|}{ After } & \multicolumn{2}{|c|}{ Before } & \multicolumn{2}{|c|}{ After } & \multirow{2}{*}{ Before } & \multirow{2}{*}{ After } \\
\hline & No & $\%$ & No & $\%$ & No & $\%$ & No & $\%$ & & \\
\hline Mild & & & & & & & & & \multirow{3}{*}{$\begin{array}{c}\text { FET }=1.964 \\
\mathrm{P}=0.161\end{array}$} & \multirow{3}{*}{$\begin{array}{c}\mathrm{FET}=0.741 \\
\mathrm{P}=0.389\end{array}$} \\
\hline FEV $1 \geq 80 \%$ predicted & 4 & 13.3 & 4 & 13.3 & 1 & 3.3 & 2 & 6.7 & & \\
\hline FET and $P$ within group & \multicolumn{4}{|c|}{-} & \multicolumn{4}{|c|}{$\begin{array}{c}\mathrm{FET}=0.351 \\
\mathrm{P}=0.554\end{array}$} & & \\
\hline $\begin{array}{l}\text { Moderate } \\
50 \% \leq \mathrm{FEV} 1<80 \% \\
\text { Predicted }\end{array}$ & 18 & 60 & 26 & 86.7 & 21 & 70 & 28 & 93.3 & \multirow{2}{*}{$\begin{array}{c}\text { FET }=0.659 \\
\mathrm{P}=0.417\end{array}$} & \multirow{2}{*}{$\begin{array}{c}\text { FET }=0.741 \\
\mathrm{P}=0.389\end{array}$} \\
\hline FET and $P$ within group & \multicolumn{4}{|c|}{$\begin{array}{l}\mathrm{FET}=5.455 \\
\mathrm{P}=0.019^{*}\end{array}$} & \multicolumn{4}{|c|}{$\begin{array}{l}\mathrm{FET}=5.454 \\
\mathrm{P}=0.018^{*}\end{array}$} & & \\
\hline$\frac{\text { Severe }}{30 \% \leq \mathrm{FEV} 1<50 \% \text { predicted }}$ & 8 & 26.7 & 0 & 0 & 8 & 26.7 & 0 & 0 & \multirow{2}{*}{$\begin{array}{l}\mathrm{FET}=- \\
\mathrm{P}=-\end{array}$} & \multirow{2}{*}{$\begin{array}{l}\mathrm{FET}=- \\
\mathrm{P}=-\end{array}$} \\
\hline FET and $P$ within group & \multicolumn{4}{|c|}{ - } & \multicolumn{4}{|c|}{-} & & \\
\hline$\frac{\text { Very Severe }}{\text { FEV } 1<30 \text { of predicted }}$ & 0 & 0 & 0 & 0 & 0 & 0 & 0 & 0 & \multirow{2}{*}{$\begin{array}{c}\mathrm{FET}=- \\
\mathrm{P}=-\end{array}$} & \multirow{2}{*}{$\begin{array}{l}\text { FET }=- \\
P=-\end{array}$} \\
\hline FET and $P$ within group & & & & & & & & & & \\
\hline
\end{tabular}

FET $=$ The Fisher's exact test.

*Significant difference at $\mathrm{P}$ level $\leq 0.05$.

FEV1: Forced expiratory volume in first second. 


\section{References}

1. Rosdahl CB, Kowalski MT.Textbook of Basic Nursing .8th ed. Philadelphia: Lippincott, 2002; 1391-6.

2. Daniels R, Nosek L. Contemporary Medical- Surgical Nursing. Australia: Thomson, 2007; 504-7.

3. Behrendt CE. Mild and moderate-tosevere COPD in nonsmokers. Chest 2005; 128(6):1239-44.

4. Nour A. Measures Used by Patients with COPD to Manage the Sensation of Dyspnea. Unpublished Master thesis, Faculty of Nursing, University of Alexandria, 2001.

5. Mannino MD. COPD: epidemiology, prevalence, morbidity and mortality and disease heterogeneity. Chest 2002; 121 (5): 1215-65.

6. Buist A, Vollmer W, Bureny R. International variation in the prevalence of COPD: a population-based prevalence study. Lancet 2007; 370(9589): 741-50.

7. Godtfredsen N, Lam T, Hansel T, Burns D, Vestbo J. COPD-related morbidity and mortality after smoking cessation: status of the evidence. Eur Respir Journal 2008; 32 (4): 844-53.

8. Amer M, Wahba H, Ashmawi S, Mabrouk R, Sharaf Eldeen A, Hamza S. Proinflammatory cytokines in Egyptian elderly with chronic obstructive pulmonary disease. Lung India 2010; 27(4): 225-29.

9. Statistical record in the Main University Hospital in medical Chest disease Department, 2010.

10. Blanc P, Iribarren C, Trupin L, Earnest G, Katz P, Balmes J, Sidney S, Eisner $M$. Occupational exposures and the risk of COPD: dusty trades revisited. Thorax 2009; 64(1):6-12.
11. Gas B. Introduction to patient care: A comprehensive approach to Nursing. $3^{\text {rd }}$ ed. Philadelphia: W.B Saunders, 1997; 594.

12. Kumar V, Cotran RS, Robbins SL. Robbins basic Pathology. $7^{\text {th }}$ ed. Philadelphia: Mosby, 2003; 460-2.

13. Kaiser S. COPD - Causes and risk factors 2009. Available at: http://www.euphix.org/object documen t/o4734n27163.html. Retrieved on: 27/10/2011.

14. Neematallah R. The relationship between inflammatory markers and disability in chronic obstructive pulmonary disease. Unpublished master thesis, Faculty of Medicine, University of Alexandria, 2010.

15. Retamales I, Elliot WM, Meshi B, Coxson HO. Amplification of inflammation in emphysema and its association with latent adenoviral infection .Am J Respir Crit Care Med 2001;164(3): 469-73.

16. Hogg JC. Pathophysiology of airflow limitation in chronic Obstructive pulmonary disease. Lancet 2004; 364(9435):709-21.

17. Hogg JC, Chu F, Utokaparch S, Woods R, Elliott WM, Buzatu L. The nature of small-airway obstruction in chronic obstructive pulmonary disease. N Engl J Med 2004; 350(26):2645-53.

18. Barbera JA, Peinado VI, Santos S. Pulmonary hypertension in chronic obstructive pulmonary disease. Eur Respir J 2003; 21(5):892-905.

19. Weitzenblum E. Severe pulmonary hypertension in COPD. Chest 2005; 127(5): 1480-2.

20. Broekhuizen B, Sachs A, Oostvogels R, Hoes A, Moons K. The diagnostic value of history and physical examination for COPD in suspected or known cases: a 
systematic review. Family Practice 2009; 86(1):204-17.

21. Pellegrino R, Viegi G, Brusasco V, Crapo RO, Burgos F, Casaburi R. Interpretative strategies for lung function tests. Eur Respir J 2005; 26(5):948-68.

22. Spirometry for diagnosis of COPD and adult asthma. Available at: http://www.mmc.org/workfiles/mh. Retrieved on: 21/11/2011.

23. Timothy J, Barreiro D, perillo I. An Approach to Interpreting Spirometry. Am Fam Physician 2004; 69(5):110715.

24. Johannessen A, Lehmann S, Omenaas ER, Eide GE, Bakke PS, Gulsvik A. Post-bronchodilator spirometry reference values in adults and implications for disease management. Am J Respir Crit Care Med 2006; 173(12):1316-25.

25. Moullec E, Grégory R, Laurin H, Lavoie D, Kim S. Effects of pulmonary rehabilitation on quality of life in chronic obstructive pulmonary disease patients. Current Opinion in Pulmonary Medicine 2011; 17 (2): 62-71.

26. Sharma S. Pulmonary Rehabilitation .Available at: http://www.emedicine.medscape.com/ar ticle/319885overview. Retrieved on: 20/12/2011.

27. Jeffrey M, Donty V. Pulmonary Rehabilitation. Pulmonary - Critical Care Associates of East Texas. Available at: http://www.pcca.net/PulmonaryRehabili tation.html. Retrieved on: 20/12/2011.

28. Butcher SJ, Jones RL.The impact of exercise training intensity on changes in physiological function in patients with chronic obstructive pulmonary disease. Sports Med 2006; 36(4):30725.
29. Ourbeau J, Julien M, Maltais F, Rouleau M, Beaupre A, Begin R, Renzi P, Nault D, Borycki E, Schwartzman K. Reduction of hospital utilization in patients with chronic obstructive pulmonary disease. Arch Intern Med 2003; 163(4):585-91.

30. Bauldof G. How to help patients with COPD? American Nurse Today 2009; 13(8):1-10.

31. Krstev S, Ji B, Shu X, Gao Y. Occupation and chronic bronchitis among Chinese women. J Occup Environ Med 2008; 50(1):64-71.

32. Bartolome R, Celli F. The Importance of Spirometry in COPD and Asthma, Effect on Approach to Management. Chest 2000; 117 (2):155-95.

33. Thompson J, Mcfarland G, Hirsch J, Tucker S. Clinical Nursing. $5^{\text {th }}$ ed. Philadelphia: Mosby, 2002; 171-3.

34. Sandra L. Oxygen Saturation Monitoring by Pulse Oximetry. AACN Procedure manual for Critical Care. $4^{\text {th }}$ ed: St.Louis: Saunders, 2001; 12.

35. Sundblad BM, Larsson K, Nathell L. High rate of smoking abstinence in COPD patients: Smoking cessation by hospitalization. Nicotine Tob Res 2008; 10(5):883-90.

36. Izadi F, Hajbaghery M. Effects of Pursed lips breathing on ventilation and activities of daily living in patient with COPD.Webmed Central Rehabilitation 2011; 2(4): 1904-15.

37. Kim DS, Kim YS, Chang JH, Lim CM, Lee JH, Uh ST, Shim JJ, Lew WJ. Prevalence of Chronic Obstructive Pulmonary Disease in Korea: A Population-based Spirometry Survey. Am J Respir Crit Care Med 2005; 1729(3):842-7.

38. Stang P.The Prevalence of COPD: Using Smoking Rates to Estimate Disease Frequency in the General Population. Chest 2000; 117(5):2-15. 
39. Zhong N, Wang C, Yao W, Chen P, Kang J, Huang S, Chen B, Ni D, Zhou Y, Liu S, Zheng J, Ran P. Prevalence of Chronic Obstructive Pulmonary Disease in China: A Large, Population-based Survey. Am J Respir Crit Care Med 2007; 176(8): 753-60.

40. Silverman E, Weiss S, Drazen J, Chapman H. Gender-Related Differences in Severe, Early-Onset Chronic Obstructive Pulmonary Disease. 2000; 162 (6): 2152-8.

41. Ansari M, Rao1 B, Koju R, Shakya R. Impact of pharmaceutical intervention on inhalation technique. Journal of science, engineering and technology 2005; 1(1):1-10.

42. Johnson $P, \quad$ Balakrishnan K, Ramaswamy P, Ghosh S, Sadhasivam M, Abirami O, Sathiasekaran B, Kirk R. Prevalence of chronic obstructive pulmonary disease in rural women of Tamilnadu: implications for refining disease burden assessments attributable to household biomass combustion._Glob Health Action 2011; 4(4):7226.

43. Lindberg A. Chronic obstructive pulmonary disease (COPD): Prevalence, incidence decline in lung functions and risk factors. Int J Tuber Lung Dis 2005; 9(8):926-32.

44. Ekici A, Ekici M, Kurtipek E. Obstructive airway diseases in women exposed to biomass smoke. Environ Res 2005; 99(4): 93-8.

45. Pirkle JL, Bernert JT, Caudil SP,Sonsonoff CS, Pechaceck TF.Trends in the exposure of nonsmokers in the US population to secondhand smoke. Environ Health Prespect 2006; 114(6): 853-8.

46. Backerman M, Magadle R, Weiner M,Weiner $P$. The effects of specific Inspiratory Muscle Training in patients with COPD. Chest 2005; 128(5): 317782.
47. Klaus F. Improving Dyspnea in Chronic Obstructive Pulmonary Disease Optimal Treatment Strategies .Am Thorac Soc 2006; 3 (3): 270-5.

48. Avanji F. The effect of pursed lips breathing on ventilation and activity of daily living in patients with COPD. Webmed Central Rehabilitation 2011; 2(4): 1904-11.

49. Spahija J, Marchie M, Grassino A. Effect of imposed pursed-lips breathing on respiratory mechanics and dyspnea at rest and during exercise in COPD. Chest $2005 ; 128(2): 640$.

50. Vitacca E, Clini L, Bianchi N. Acute effects of deep diaphragmatic breathing in COPD patients with chronic inspiratory insufficiency. European Respiratory journal 1998; 11(4):408-15.

51. Jyothy M. A Study on Effectiveness of Deep Breathing Exercise on Pulmonary Function among Patients with Chronic Airflow Limitation. International Journal of Nursing Education 2011; 3(2):34-7.

52. Gosselink R, Wagenaar R, Rijswijk H, Sargeant A, Decramer M. Diaphragmatic breathing reduces efficiency of breathing in patients with chronic obstructive pulmonary disease Am J Respir Crit Care Med 1995; 151 ( 4): 1136-42.

53. Hem Y, Ciçek H, Akbayrak Y. The Effects of Breathing Exercises on Pulmonary Functions Tests and Arterial Blood Gas for the Patients with Chronic Obstructive Pulmonary Disease (COPD). Gulhane Med J 2004; 46(1): 1 9.

54. Fregonezi G, Resqueti V, Rous R. Pursed Lips Breathing. Pulmonary Medicine 2004; 40(4):167-70.

55. Dechman G, Wilson C. Evidence Underlying Breathing Retraining in People with Stable Chronic Obstructive Pulmonary Disease._Physical Therapy 2004; 84(12): 1189-97. 
56. Roa J, Epstein S, Breslin E, Shannon T, Celli B. Work of breathing and ventilatory muscle recruitment during pursed lips breathing in patients with chronic airway obstruction .Am Rev Respir Dis 1999; 143(3):77-85.

57. Louise R. Vital Signs. American Journal of Nursing 2010; 110 (5): 11-15.

58. Ramos E, Vanderlie L, Ramos D, Veloso M. Influence of pursed lips breathing on heart rate variability and cardiorespiratory parameters in subjects with Chronic Obstructive Pulmonary Disease. Eur Respir J 2010; 35(4):549.

59. Kulur A, Haleagrahara N, Adhikary P. Effect of diaphragmatic breathing on heart rate variability in ischemic heart disease with diabetes. Arq. Bras. Cardiol 2009; 92(6): 93-8. 